\title{
Obesity as a Complex Chronic Disease
}

\author{
Walter Suárez Carmona ${ }^{1}$, Elena Carrillo Álvarez ${ }^{2}$ and Antonio Jesús Sánchez Oliver ${ }^{3 *}$ \\ ${ }^{1}$ Universidad Pablo Olavide de Sevilla, Spain \\ ${ }^{2}$ Facultat de Ciències de la Salut Blanquerna, Universitat Ramon Llull, Spain \\ ${ }^{3}$ Facultad de Ciencias del Deporte, Universidad Pablo de Olavide de Sevilla, Spain
}

Submission: March 28, 2018; Published: April 19, 2018

*Corresponding author: Antonio Jesús Sánchez Oliver, Universidad Pablo de Olavide de Sevilla, Facultad de Ciencias del Deporte, España, Spain, Tel: +34656305480; Email: asanchez@upo.es

\section{Abstract}

Obesity is a chronic disease of multifactorial origin, with a high prevalence worldwide that is associated with potentially serious complications and that requires a multidisciplinary approach. Due to its high clinical impact and high health cost. Obesity is a global health problem, being considered one of the most serious and prevalent non communicable diseases of the $21^{\text {st }}$ century. The aim of this review is to present the current approaches to the physiopathology of obesity, with adipose tissue as its focus. We argue that a thorough understanding of the alterations that occur in the adipose tissue in situations of obesity can provide a strong basis upon which building prevention and treatment strategies

Keywords: Chronic disease; Obesity; Pathophysiology; Adipose tissue; Pandemics

\section{Introduction}

Obesity is one of the greatest challenges that current societies face. Its prevalence and serious consequences led to label it as the " $21^{\text {st }}$ century pandemic" in 2004; coining the term "globosity" in 2010 in view of the alarming reality and the perspective of no improvement in the short term [1,2].

The primary difficulty to tackle this situation starts on how is defined. In 1997, the WHO defined it as an excess of fat accumulation that harms health [3]. This conceptualization constitutes the first challenge addressing obesity, since it does not establish the extent of fat accumulation that becomes harmful-while we recognize that this is a very complicated variable to be quantified. In 2003, Cummings and Schwartz introduced the concept of genetic and environmental load that accompanies this pathology and define it as an oligogenic disease, whose expression can be modulated by numerous modifying genes that interact with each other and, also, with environmental factors [4]. Recently, Pasco \& Montero [5] went further and defined obesity as a systemic, multiorganic, metabolic and chronic inflammatory disease, multi determined by the interrelation between the genomic and environmental factors, and phenotypically expressed by an excess of body fat (in relation to the organism that houses it), which entails a greater risk of morbidity and mortality. In comparison to the previous ones, this last definition takes greater consideration of the clinical aspects of the diseases, while also taking into account the anthropometric indicators of risk.
Thus, obesity must be understood as a chronic, multifactorial and multicausal disease, which corresponds to an alteration of the correct function of adipose tissue in its capacity to store fat, both quantitatively and qualitatively. This alteration leads to a situation of inflammation of this tissue, closely linked to an extended metabolic malfunctioning, ultimately related to metabolic syndrome [6,7]. Insulin resistance appears concomitantly, establishing a link between obesity and the metabolic disturbances that accompany it, without a clear division between both phenomena $[8,9]$.

The aim of this mini-review is to present obesity as a complex chronic disease based on the current approaches to its physiopathology, and with adipose tissue as its focus.

\section{Discussion}

The adipocyte is the main cell of the adipose tissue, and its main function is that of storing excess energy in the form of triglycerides in their lipid bodies and releasing them in situations of energy need. Since its discovery as an endocrine cell, it is known that the adipocyte plays an active role both in the energetic balance and in numerous physiological and metabolic processes [10-12]. Even though approximately 600 bioactive factors are nowadays considered adipokines (cytokines released by the adipose tissue), we are largely unaware of the function and mechanisms of action and signalling of many of the recently discovered adipokines $[13,14]$. Leptin and adiponectin are still the most investigated adipokines, trying to provide a deeper 
understanding of their role at a general level and in the context of obesity $[15,16]$. Obesity has been associated with a disturbance of the releasing profile of both the adipose tissue and the adipocyte, causing an alteration of the leptin/adiponectin ratio secretion [10]. In this way, in a context of lipo-inflammation, an increase in serum leptin levels accompanied by a decrease in adiponectin occurs, which does not correspond to the fatty tissue levels $[10,16]$. Moreover, Leptin plays an immunomodulator role that, together with the anti-inflammatory and sensitizing role of insulin at a systemic level of adiponectin, constitutes a secretary profile that can partly explain the metabolic abnormalities associated with obesity, as the low-grade inflammation [16,17].

The adipose tissue is composed of adipocyte and stroma (reticular connective tissue that confers adipocyte and vascularisation and innervations), along with various cells (macrophages, $\mathrm{T}$ cells, fibroblasts, preadipocyte, mesequimal cells, pericytes, etc. which make up the cellular microenvironment [11]. Immune cells from the adipose tissue also have the function of releasing inflammation-related factors that become essential to understand how obesity conditions may foster inflammation [18]. It has been observed that, in obesity situations, most proinflammatory cytokines are emitted by M1 macrophages or "classically activated" adipose tissue macrophages, which become greatly increased by the infiltration of circulating monocytes, attracted by chemo attractant substances and by local proliferation [19]. It has been recently suggested that such local proliferation from resident macrophages precedes infiltration, thus initiating the accumulation of macrophages in the tissue [20].

Adipocyte can be developed through two processes: hypertrophy (increasing its size) and hyperplasia (increasing its number from a precursor cell -preadipocyte- to a mature adipocyte through a series of steps). It has been traditionally considered that, at a certain moment in the growth of an adipocyte, as its volume of fat (hypertrophy) increases, it will reach a threshold of critical size in which there will be a process of hyperplasia, stimulating a precursor cell and, thus, generating, a new fat cell [21]. It is now widely accepted that this is a process strongly regulated by many factors and that the single exposure to an excess caloric intake causes the precursor cells to start proliferating at the visceral level without the need for a signal from the hypertrophied adipocyte [22].

Apparently, once the threshold size has been exceeded, the hypertrophied adipocyte will present a disfunctional activity. altering its relationship with the circulating microenvironment. Hypertrophy in large adipocyte has been associated with an increased emission of inflammatory factors and/or impaired insulin sensitivity in both animal models and humans [23]. Depending on their location, adipose cells of the different fatty deposits will have a certain average size, a greater or lesser capacity for hypertrophy and/or hyperplasia, a differentiated secretary profile, and a greater or lesser local or systemic relevance. This is a very representative fact, since the accumulation of obesity at the central level has been pointed out as the best predictor of cardio metabolic diseases associated with obesity, at the same time that visceral fat is greatly associated with adverse effects than peripheral or subcutaneous fat [23]. At the onset of hypertrophy development, there is a transient state of inflammation that is considered necessary and even healthy [24]. The problem arises when this situation is perpetuated, since it compromises the integrity of the adipocyte, hypertrophied in excess, modifying its metabolic behaviour and generating adaptations in the tissue, which, ultimately, might lead to apoptosis [25]. At this point, an infiltration of immune cells of proinflammatory profile would occur, altering the cellular microenvironment, and generating a state of tissue inflammation known as lipo-inflammation [26,27].

This phenomenon would release to the circulation inflammatory factors that can travel to other tissues, causing alterations in them that, in the end, create a low-grade systemic inflammatory condition [28]. In these circumstances, a situation of hypoxia happens, which together with the alteration of angiogenesis and the alteration of the extracellular matrix (fibrosis), further aggravates its inflammatory situation $[29,30]$.

The greater size of the adipocyte, together with the concomitant inflammatory state conditions its functioning in, at least, six ways [31]:

A. Altering its secretary profile with a greater production of leptin and less adiponectin (which inhibits its expression by inflammatory factors such as TNF $\alpha$ ),

B. Causing a lower sensitivity to insulin,

C. Leading to a worse mitochondrial function and to a greater stress of the endoplasmic reticulum,

D. Producing a greater basal lipolysis,

E. Altering the cellular cytoskeleton, and

F. Causing a lower rate of de novo lipogenesis.

This increase of basal lipolysis is known as the "overflow hypothesis". According to it, the adipocyte has saturated its capacity to deposit triglycerides and, these are directed to other tissues, being ectopically deposed in them, thus generating lipotoxicity and resistance to insulin $[32,33]$. The increase in the flow of free fatty acids, together with the inflammatory factors, turns a situation of insulin resistance and local inflammation into a state of systemic insulin resistance and low-grade chronic inflammation [34,35].

In this inflammatory situation, and in the face of an incompetent subcutaneous adipose tissue, visceral adipose tissue becomes the first store of triglycerides due to its limited hyperplasic capacity, its characteristic hypertrophy development, together with the greater response to catecholamine's and lower insulin inhibitory response to lipolysis [36,37]. Therefore, the 


\section{Current Research in Diabetes \& Obesity Journal}

ability of an adequate adipose tissue expansion (hyperplasia versus hypertrophy), is what largely determines the existence of obese metabolically healthy subjects and metabolically ill thin subjects; although currently, the metabolically healthy obese phenotype is considered as a transition state to disease [38-40].

Obesity does not only change physical appearance: many other structures and processes are affected. Hunger (physiological), appetite (hedonic), satiety and energy balance are regulated by a redundant neuroendocrine system that is integrated at the level of the hypothalamus [41]. A dense and complex network of neurohormonal circuits make up a system where molecular signals (central and peripheral; short and long duration) are crossed, which, in turn, are integrated with signals from the mechanical, cognitive and sensory environment, all of them altered in obesity $[42,43]$. In obesogenic environments-like many current societies, where there is AN easy access to food and where many of these are highly processed-the person with obesity is forced into a futile struggle. Individuals become not only a victim, but are also criminalized for their condition, being blamed for their lack of willpower or irresponsibility, which sometimes is even exerted by health professionals themselves [44-47].

\section{Conclusion}

With the pandemic proportions reached by obesity, it is crucial to be aware of the factors that drive the risk of chronic disease in overweight and obese patients. Age, sex, genetics, ethnicity, hormonal factors, diet, level of physical activity/ exercise, pharmacological agents, and other factors such as smoking or stress are some of them. Although an increase in total body fat is associated with increased risk to health, the amount of abdominal fat, particularly, when it is placed inside the abdominal cavity, has been associated with a greater risk of morbidity and mortality, mediated by different entities: type 2 diabetes, heart disease, stroke, sleep apnea, hypertension, dyslipidemia, insulin resistance, inflammation, and some types of cancer.

While new evidence in the field of genetics make the development of tests that allows the classification of patients in several subgroups possible, further permitting to apply more personalized treatments, the formulation of more effective ways of prevention and treatment methods is imperative, before the considerable impact that excess weight has in individuals' quality of life and in societies in general. The design of new programs aimed to help obese individuals change their dietary habits and their levels of physical activity, combined, if necessary, with new safe pharmacological approaches, to diminish the excess of visceral/ectopic fat, should improve our ability to cope with the devastating consequences of this pandemic, which has unfortunately been inefficiently evaluated with the body mass index indicator (BMI). We expect that this mini-review will help to understand and pave the way for the development of better tools by all the stakeholders involved.

\section{Conflict of Interest}

Authors declare there aren't any economic interest or conflict of interest.

\section{References}

1. Ahmad SI, Imam SK (2015) Obesity: a practical guide. Springer.

2. World Health Organization (2015) Obesity and overweight: World Health Organization.

3. World Health Organization (1997) Obesity: preventing and managing the global epidemic: report of a WHO Consultation on Obesity. Genevea, Switzerland.

4. Cummings DE, Schwartz MW (2003) Genetics and pathophysiology of human obesity. Annual review of medicine 54(1): 453-471.

5. Pasca AJ, Montero JC (2015) El Corazón del Obeso. Buenos Aires (Argentina): Intermedica.

6. Grundy SM (2016) Overnutrition ectopic lipid and the metabolic syndrome. Journal of Investigative Medicine 64(6): 1082-1086.

7. Virtue S, Vidal Puig A (2008) It's not how fat you are, it's what you do with it that counts. PLoS biology 6(9): e237.

8. Gallagher EJ, Leroith D, Karnieli E (2010) Insulin resistance in obesity as the underlying cause for the metabolic syndrome. Mount Sinai Journal of Medicine: A Journal of Translational and Personalized Medicine 77(5): 511-523.

9. Lumeng CN, Saltiel AR (2011) Inflammatory links between obesity and metabolic disease. The Journal of clinical investigation 121(6): 21112117.

10. Blüher M, Mantzoros CS (2015) from leptin to other adipokines in health and disease: facts and expectations at the beginning of the $21^{\text {st }}$ century. Metabolism-Clinical and Experimental 64(1): 131-145.

11. Frühbeck G (2010) Overview of adipose tissue and its role in obesity and metabolic disorders. In: Yang K (Ed.), Adipose Tissue Protocols. ( $2^{\text {nd }}$ edn), Humana Press, Totowa, USA, pp. 1-22.

12. Blüher M (2014) Adipokines-removing road blocks to obesity and diabetes therapy. Mol Metab 3(3): 230-240.

13. Dahlman I, Elsen M, Tennagels N, Korn M, Brockmann B, et al. (2012) Functional annotation of the human fat cell secretome. Arch Physiol Biochem 118(3): 84-91.

14. Lehr S, Hartwig S, Sell H (2012) Adipokines: a treasure trove for the discovery of biomarkers for metabolic disorders. Proteomics Clin Appl 6(1-2): 91-101.

15. Friedman JM, Mantzoros CS (2015) 20 years of leptin: from the discovery of the leptin gene to leptin in our therapeutic armamentarium. Metabolism 64(1): 1-4

16. Wang ZV, Scherer PE (2016) Adiponectin, the past two decades. J Mol Cell Biol 8(2): 93-100.

17. Naylor C, Petri WA (2016) Leptin regulation of immune responses. Trends Mol Med 22(2): 88-98.

18. Schipper HS, Prakken B, Kalkhoven E, Boes M (2012) Adipose tissueresident immune cells: key players in immunometabolism. Trends Endocrinol Metab 23(8): 407-415.

19. Mraz M, Haluzik M (2014) The role of adipose tissue immune cells in obesity and low-grade inflammation. J Endocrinol 222(3): R113-R127.

20. Zheng C, Yang Q Cao J, Xie N, Liu K, et al. (2016) Local proliferation initiates macrophage accumulation in adipose tissue during obesity. Cell Death Dis 7(3): 2167. 


\section{Current Research in Diabetes \& Obesity Journal}

21. Suárez Carmona W, Sánchez Oliver AJ, González Jurado JA (2017) Fisiopatología de la obesidad: Perspectiva actual. Revista chilena de nutrición 44(3): 226-233.

22. Rosen ED (2015) Two paths to fat. Nature Cell Biology 17(4): 360-361.

23. Klöting N, Blüher M (2014) Adipocyte dysfunction, inflammation and metabolic syndrome. Reviews in Endocrine and Metabolic Disorders 15(4): 277-287.

24. Asterholm IW, Tao C, Morley TS, Wang QA, Delgado Lopez F, et al. (2014) Adipocyte inflammation is essential for healthy adipose tissue expansion and remodeling. Cell metabolism 20(1): 103-118.

25. Lafontan M (2014) Adipose tissue and adipocyte dysregulation Diabetes \& metabolism 40(1): 16-28.

26. Hotamisligil GS, Shargill NS, Spiegelman BM (1993) Adipose expression of tumor necrosis factor-alpha: direct role in obesity-linked insulin resistance. Science 259(5091): 87-91.

27. Izaola O, de Luis D, Sajoux I, Domingo JC, Vidal M (2015) Inflamación y obesidad (lipoinflamación). Nutricion hospitalaria 31(6): 2352-2358.

28. León Pedroza JI, González Tapia, LA, del Olmo Gil E, Castellanos Rodríguez D, Escobedo G, et al. (2015) Inflamación sistémica de grado bajo y su relación con el desarrollo de enfermedades metabólicas: de la evidencia molecular a la aplicación clínica. Cirugía y Cirujanos 83(6) 543-551.

29. Buechler C, Krautbauer S, Eisinger K (2015) Adipose tissue fibrosis. World journal of diabetes 6(4): 548-553.

30. Trayhurn P (2013) Hypoxia and adipose tissue function and dysfunction in obesity. Physiological reviews 93(1): 1-21.

31. Laforest S, Labrecque J, Michaud A, Cianflone K, Tchernof A (2015) Adipocyte size as a determinant of metabolic disease and adipose tissue dysfunction. Crit Rev Clin Lab Sci 52(6): 301-313.

32. Guilherme A, Virbasius JV, Puri V, Czech MP (2008) Adipocyte dysfunctions linking obesity to insulin resistance and type 2 diabetes. Nature reviews Molecular cell biology 9(5): 367-377.

33. Poirier P (2014) Exploring the spectrum of diseases influenced by excess adiposity. Transl Res 164(4): 278-283.

34. Choe SS, Huh JY, Hwang IJ, Kim JI, Kim JB (2016) Adipose tissue remodeling: its role in energy metabolism and metabolic disorders. Frontiers in endocrinology.
35. Saltiel AR (2015) Insulin signaling in the control of glucose and lipid homeostasis. Handb Exp Pharmacol 233: 51-71.

36. Moreno Indias I, Tinahones FJ (2015) Impaired adipose tissue expandability and lipogenic capacities as ones of the main causes of metabolic disorders. Journal of diabetes research.

37. Tchernof A, Després JP (2013) Pathophysiology of human visceral obesity: an update. Physiological reviews 93(1): 359-404.

38. Palmer BF, Clegg DJ (2015) The sexual dimorphism of obesity. Molecular and cellular endocrinology 402: 113-119.

39. Gustafson B, Hedjazifar S, Gogg S, Hammarstedt A, Smith U (2015) Insulin resistance and impaired adipogenesis. Trends in Endocrinology \& Metabolism 26(4): 193-200.

40. Virtue S, Vidal Puig A (2010) Adipose tissue expandability, lipotoxicity and the metabolic syndrome-an allostatic perspective. Biochim Biophys Acta 1801(3): 338-349.

41. Palma JA, Iriarte J (2012) Regulacion del apetito: bases neuroendocrinas e implicaciones clínicas. Medicina Clínica 139(2): 70-75.

42. Amin T, Mercer JG (2016) Hunger and satiety mechanisms and their potential exploitation in the regulation of food intake. Curr Obes Rep 5(1): 106-112.

43. Morton GJ, Meek TH, Schwartz MW (2014) Neurobiology of food intake in health and disease. Nat Rev Neurosci 15(6): 367-378.

44. Valdearcos M, Xu AW, Koliwad SK (2015) hypothalamic inflammation in the control of metabolic function. Annu Rev Physiol 77: 131-160.

45. De Git KC, Adan RA (2015) Leptin resistance in diet-induced obesity: the role of hypothalamic inflammation. Obes Rev 16(3): 207-224.

46. Jackson SE, Beeken RJ, Wardle J (2014) Perceived weight discrimination and changes in weight, waist circumference, and weight status. Obesity 22(12): 2485-2488

47. Spahlholz J, Baer N, König HH, Riedel Heller SG, Luck Sikorski C (2016) Obesity and discrimination-a systematic review and meta-analysis of observational studies. Obes Rev 17(1): 43-55.

\begin{tabular}{l} 
Your next submission with Juniper Publishers \\
will reach you the below assets \\
- Quality Editorial service \\
- Swift Peer Review \\
- Reprints availability \\
- E-prints Service \\
- Manuscript Podcast for convenient understanding \\
- Global attainment for your research \\
- Manuscript accessibility in different formats \\
( Pdf, E-pub, Full Text, Audio) \\
- Unceasing customer service \\
Track the below URL for one-step submission \\
https://juniperpublishers.com/online-submission.php \\
\hline
\end{tabular}

